\title{
The Application of Flipped Classroom in Vocational English Teaching
}

\author{
Ying Wei \\ Foreign Language School \\ Huanghe Science and Technology College \\ Zhengzhou, China
}

\begin{abstract}
At the present time, "flipped classroom" mode has attracted more and more attention, especially some trials have been put into practice and gained much teaching progress. This thesis attempts to explore the application of flipped classroom in vocational English teaching through the analysis of its features and mode as well as the present situation of vocational students and vocational English teaching methods.
\end{abstract}

Keywords—flipped classroom; vocational English teaching

\section{INTRODUCTION}

Along with the development of information technology, "Big data", "Moocs", "flipped classroom" have aroused great attention in the education field. Some Medias have announced that the "big data" age of education has arrived; more and more teachers have attempted many advanced carriers, devices and internet to make classes flipped and more efficient. The flipped class in vocational English teaching is taken as an example as follows.

\section{FLIPPED CLASSROOM}

Jonathan Bergmann and Aaron Sams-two chemistry teachers of American Woodland Park High School were the first to formally put forward the concept of "flipped classroom" in 2007. They recorded their lectures and posted them online in order to accommodate students who missed their classes. In the following years, more educators and teachers have studied how to carry out "flipped class" in actual teaching on basis of the features of their classes. Actually, how to flip the class, what to flip, how teachers should do to make preparations and other detailed questions are worth our deep thinking and studying.

Some researchers noted that for flipped classroom, teaching videos prepared by the teacher or third parties are used to deliver teaching contents, which students have finished watching and studying outside the class by themselves, and during class more time can be spent in class on higher-level thinking skills such as problem-finding, collaboration, debate or speech presentation, design and problem solving and group working to consolidate their knowledge and skills. The author believes that "flipped classroom" promotes students' selfdirected studying, inquiry learning, and shifts traditional "teachers-centered" mode to fresh-newly "students-centered" mode. With the high development of intelligent mobile devices, the spread of internet and the application of more APPs, online lessons are increasingly popular, which are the premise of "flipped classroom" in college class.

\section{PRESENT Situation OF Vocational ENGLish}

Nowadays, vocational colleges are faced with more and more challenges: unstable source of students, vast differences among students, out-of-date teaching methods, backward teaching devices and so on. All in all, teaching mode falls behind, which can't meet the needs of students.

\section{A. Students'Learning Situation}

Most students in vocational college with poor studying foundation and weariness mind, has little interest in English learning. While some students' desire for great improvements in English skills during college, but they actually lack good foundation and proper studying method. In this case, their studying effect is not satisfying; what's more they lose selfconfidence and interest in English learning. As for their academic studying, certain kinds of English knowledge are essential, such as medical English, IT English, communicative English and so on. For example, as learned from students of Traffic School who were sent to Toyota Zhengzhou 4S shop for internship, they met many academic words about automobiles especially when mending imported cars and searching information from foreign websites. The author considers that vocational college teachers are expected to update their common English knowledge and master some knowledge for ESP teaching.

\section{B. English Teaching Situation}

Unchanging educational concepts and teaching methods make teaching mode of vocational English is out of date and boring; backward teaching devices such as chalk, blackboard cause students' poor interest in English learning. Furthermore, students' passive class involvement can't stimulate teachers to improve current teaching mode.

\section{INTRODUCTION OF FLIPPED CLASSROOM IN VOCATIONAL ENGLISH TEACHING}

"Flipped classroom" in vocational English teaching aims to change traditional teacher-centered mode, to develop students' learning independence and ability to explore problems. To 
boost its application, educators and teachers are expected to take full advantage of various high-qualified education resources and combine modern educational technology with class teaching. "Flipped classroom" is a good opportunity to better adapt to reform modern English teaching mode.

\section{A. Pre-class Preparations}

"Flipped classroom" requires that teachers, with the consideration of expected knowledge aims and ability aims for students, should give an overall design for teaching content of a whole unit, lay out proper teaching plans and record teaching videos before class. Students self-study online teaching videos by using computers or mobile phones, which can be more personalized for the reason that they can plan and control the study period according to their own situations, for example, they can fast forward the part which has been well known, while they can skip back, pause, or repeat the part which is hard to understand. During the video-watching period, students pause the video when necessary, such as searching related information on the internet, asking teachers for help through chat app, or taking notes. Actually, this mode excellently meets students' need for independent learning and greatly stimulates their desire for further study. Teaching videos by applying new digital technology make abstract concepts more concrete and visual, which promotes students' interest, understanding and memorization. Knowledge-centered teaching videos have visualized teacher's thoughts and abstract concepts, which can be better and easier understood and mastered by students.

\section{B. In-class Teaching}

After students' watching related teaching videos, more time in class can be spent on students' practice, in-group discussion, presentation, problem-solving and so on, which indeed improves teaching quality. In "flipped classroom", certain inputs gained from watching teaching videos before class, which facilitates students output what they have learned in class under the teacher's guidance. While traditional teaching mode also requires students' output, but the effect is far from perfect with the time limitation after teacher's oral delivery of knowledge in class. For example, for the topic related to teaching job interview, students can learn what shall be prepared, how to prepare and how to express before the interview, through watching relevant videos before class. Therefore, students can carry out knowledge output on related topics in the class. Compared to the traditional classroom, more time could be employed to use the language in the flipped classroom. Based on the actual situation of the students and teaching contents, the flipped classroom can be divided into the following sections: content created by students, independent problems-solving and inquiry-based activities, etc. Students find their own difficulty in learning by watching the video, find their own problems through communicating among teachers and students, and seek targeted guidance from teachers. Students can also have group discussion or debate on the content of the teaching video, draw merits from others and make common progress, which thereby enhance their ability to learn English.

\section{After-School Tutoring}

After completing the teaching sections, the teacher can tutor or answer a student's question, which may have explanations for the common problems and mistakes students have encountered. Teaching can be made a lot easier through the teaching mode of "flipped classroom". Input before class, output during class, identify problems and offer specific inputs. Unlike cramming students in traditional teaching mode, students have more time and opportunities to participate in studying period.

\section{POSSIBLE PROBLEMS IN FLIPPED CLASSROOM}

\section{A. Opportunities and Challenges for Teachers}

In the flipped classroom, the teacher will ask students to watch instructional videos in advance, and knowledge could be digested by raising questions or discussions, etc, in which the teacher plays a role as a guide and supervisor. Seemingly the teaching duties of a teacher are relieved, but in fact higher requirements are raised for vocational teachers. Some might propose that high-quality lesson teaching videos of others could be directly utilized. In fact that is not the case, how does the teacher cooperate with students if he loses control of the class. If teachers yearn for a better flipped classroom, they should have the courage to update their knowledge structure, and should always keep abreast of times to master modern educational information technology. Teachers should also flip their roles from an absolute knowledge initiator to the assistant and guider of learning, regarding their students as the protagonist of the classroom.

\section{B. Opportunities and Challenges for Students}

For higher vocational college students lacking learning motivation and lower self-awareness, how to ensure that they could fulfill the video learning before a class? On the one hand, self-learning platform could be utilized to meet the students' requirements to watch teaching videos after class, monitor and ensure that students complete their learning through the interaction of relevant system; on the one hand, by taking advantage of homework and class presentation, the outcomes of their independent learning could be supervised; also, instant messaging software can be used to communicate with students in a timely manner. Students could watch the videos after class, and complete the learning objectives through face-to-face communication with teachers in classroom. This teaching model respects education and the law of personality development, providing appropriate education for each student. With respect to individual differences, "flipped classroom" facilitates students to obtain more internalization of knowledge and better improve English proficiency.

\section{CONCLUSION}

In short, "flipped classroom" is a demand for English teaching reform in higher vocational colleges, but the road twists and turns. As long as there are more vocational English teachers who are creative, bold and persistent, flipped classroom teaching model will be accepted by more and more people. And by comprehensively improving the quality of 
higher vocational English teaching, we could foster more interdisciplinary talents who are professional in their own domains as well as in English.

\section{REFERENCES}

[1] Gibert Grimes Weaver, Louis Cenci. Applied teaching techniques[M]. Cornell University. Pitman Pub. Corp, 1960.

[2] Guo Weiping, The Problems and Strategies of English Teaching in Higher Vocational College. China Adult Education, 2009 (09): 151-52.

[3] Han Lizhen, The Bottleneck and Route Choice of the Development of Flipped Classrom. Journal of Jiangsu RTV University

[4] Liu Dailin,and Zhang Jianyu, Survey and Reform Thinking of of Publish English Present Teaching Condition in Higher Vocational College. Foreign Languages in China 2015 (06) : 77-83.

[5] Mi Xiumei, The Studyof English Teaching and the Orientation of Teachers' Role in Big Data Time. China Information Technology Education. 2015(08). 